\title{
Initial experience with holmium laser enucleation of the prostate in a urology specialist hospital in Nigeria
}

\author{
Celsus Ukelina Undie* (D), Ewomazino Ibanga Nnana and Kalenebari Raymond Torporo
}

\begin{abstract}
Background: Holmium laser enucleation of the prostate (HoLEP) is a more recent procedure for the management of Benign Prostatic Hyperplasia compared to open prostatectomy or Transurethral Resection of the Prostate. HoLEP is not commonly done in Nigeria. The objective of the study was to determine whether our initial experience with HoLEP in Abuja, favourably compared to those of other centres across the world.

Methods: A retrospective study was done on 40 patients who had HoLEP between October 2018 and December 2019. Pre- and post-operative International Prostate Symptom Score (IPSS), prostate-specific antigen (PSA), prostate sizes, maximum flow rate $\left(Q_{\max }\right)$ and post-void residual urine volume (PVR) were collated. The duration of irrigation, catheterization and length of hospital stay were also recorded and analysed. Complications were documented.

Results: There were improvements in IPSS from 19.67 to 5.41 , PSA from 8.07 to $2.03 \mathrm{ng} / \mathrm{ml}, Q_{\max }$ from 11.27 to $29.67 \mathrm{ml} / \mathrm{min}$, PVR from 88.99 to $32.8 \mathrm{ml}$, while average prostate sizes reduced from 116.54 to $30.3 \mathrm{~g}$ after surgery. Following HoLEP, the duration of irrigation was $18.00 \mathrm{~h}$, catheterization was $26.76 \mathrm{~h}$ and length of hospital stay was 1.82 days. Two (5.0\%) patients were recatheterized, 4 (10.0\%) developed post-operative bladder neck stenosis.

Conclusions: The outcome of HoLEP in our experience compared favourably with those from other centres. With adequate training and requisite equipment in resource-poor environments, technical procedures like HoLEP can be embarked on with favourable results.
\end{abstract}

Keywords: Prostate, HoLEP, Laser, Outcome

\section{Background}

Lower urinary tract symptoms (LUTS) due to benign prostatic hyperplasia (BPH) are amongst the most common complaints of aging men in Urology clinics. The prevalence of moderate to severe LUTS suggestive of $\mathrm{BPH}$ in men 40 years and above increases with age ranging from $25.35 \%$ [1] to $35.3 \%$ [2], in 2 different states in Nigeria and $19.9 \%$ in Accra Ghana [3]. These symptoms are often distressing to patients and interfere enough

*Correspondence: cuundie@yahoo.com; urologist@kelinahospital.com Kelina Hospital, 3rd Avenue, Gwarinpa, PMB 48, Abuja 900001, FCT, Nigeria with their overall quality of life to make them seek medical intervention.

The American Urological Association (AUA) recommends that patients with LUTS should be evaluated with a clinical history and urinalysis. Also, uroflometry and pressure flow studies should be considered for evaluation in selected patients and prior to surgical intervention, assessment of prostate size and shape are to be considered $[4,5]$.

Based on evaluation of these patients, treatment options may be watchful waiting, pharmacological or surgical [6]. Indications for Surgery in patients with BPH include renal insufficiency, refractory urinary retention, recurrent urinary tract infection, gross haematuria and 
recurrent bladder stones due to BPH. LUTS attributed to $\mathrm{BPH}$, refractory to other therapies or in patients unwilling to use other therapies, also constitute indication for surgical intervention $[4,5]$.

For many years, transurethral resection of the prostate (TURP) was the gold standard of surgery [7-9] for patients with bothersome moderate or severe LUTS due to $\mathrm{BPH}$ who either failed, did not qualify for or did not want medical therapy. With the rapid emergence and popularization of other minimally invasive technologies, TURP as the "gold standard" for surgical treatment of BPH is being replaced with HoLEP. Gilling described HoLEP in 1996 [10] and since then, it came to be considered as a safe and effective method for treatment of BPH [11] and a preferred alternative to open prostatectomy and TURP [12].

For prostates greater in size than $80 \mathrm{~g}$, HoLEP is recommended by the European Association of Urology (EAU) as an alternative to open prostatectomy [13]. It has been shown to produce long-term functional results, better haemostatic properties, lower perioperative morbidity and shorter hospital stay [14]. It has been suggested as a size-independent, gold standard treatment of patients with lower urinary tract symptoms secondary to benign prostatic enlargement [15].

Like most surgical procedures, HoLEP is not without complications. Perioperative complications such as capsular perforation, superficial bladder mucosal injury, injury to the ureteric orifice, incomplete morcellation and the need for an additional procedure have been reported. Other complications, including clot retention, acute urinary retention requiring recatheterization and UTI sometimes occur. Post-operative urinary incontinence, transient or persistent; bladder neck contracture and urethral strictures can also complicate the procedure [16].

In Africa and indeed in Nigeria, HoLEP is a relatively novel procedure. Hindrances to the commencement of HoLEP procedure include cost, unavailability of requisite skills, and the prolonged learning curve compared to open surgery or TURP. It has been said that a Surgeon needs to perform up to 50 cases of HoLEP before proficiency is attained [17]. Mentorship is a challenge in resource-poor countries.

The objective of this study is to analyse our experience and determine if our initial outcome is favourably comparable to results in other centres.

\section{Methods}

The study was a retrospective study. It was carried out in Abuja, Nigeria. From commencement of HoLEP in October 2018, a total of 49 patients have had the procedure by December 2019. HoLEP was performed on patients with bladder outlet obstruction (BOO) secondary to $\mathrm{BPH}$. All
Table 1 Baseline pre-operative characteristics

\begin{tabular}{lrc}
\hline Characteristics & Mean & Range \\
\hline Age (years) & 65.00 & $54-81$ \\
PSA (ng/ml) & 8.53 & $0.4-57.7$ \\
Prostate size (g) & 120.20 & $22.62-509$ \\
Post-void Residual urine volume & 203.98 & $0.00-2832$ \\
$\quad(\mathrm{ml})$ & & \\
$Q_{\max }(\mathrm{ml} / \mathrm{s})$ & 9.78 & $0.00-25.5$ \\
\hline
\end{tabular}

Table 2 Peri-operative characteristics

\begin{tabular}{lcc}
\hline Characteristics & Mean & Range \\
\hline Duration of irrigation (h) & 18.00 & $0-92$ \\
Duration of catheterization (h) & 26.76 & $11-92$ \\
Length of hospital stay (days) & 1.82 & $1-4$ \\
\hline
\end{tabular}

patients had pre-operative assessment of International Prostate Symptom Score (IPSS), PSA, prostate size, PVR, and maximum flow rate $\left(Q_{\max }\right)$. Four patients were catheterized prior to presentation on account of acute urinary retention. For these patients, the $Q_{\max }$ was assumed to be 0 and residual volumes could not be estimated.

All surgeries were done by one Surgeon, the first 7 under supervision. HoLEP was done with the Lumenis $120 \mathrm{~W}$ laser, Moses Technology ${ }^{\mathrm{TM}}$. The duration of irrigation, catheterization and hospital stay were computed. Pre-operative indices were reassessed 6 months after surgery. Of the patients due for reassessment, only 12 had presented at the time this data was compiled. Results and conclusions were drawn from available data.

Data was entered into and analysed with SPSS version 25.0. Paired sample $T$-test was used to compare mean. $P$ value $<0.05$ was set to define statistical significance.

\section{Results}

Table 1 shows the baseline pre-operative parameters of the patients. The oldest patient was 81 years and the largest prostate was $509 \mathrm{~g}$. Prior to surgery, as much as $2832 \mathrm{ml}$ of urine was retained post-urination.

One patient was not irrigated at all after surgery. The longest duration of catheterization was $92 \mathrm{~h}$. Patients spent an average of 1.82 days in the hospital after surgery (Table 2).

Nine patients were excluded from this study because they were found to have other factors responsible for $\mathrm{BOO}$, including urethral injury from prior catheterization elswhere, urethral stricture found at pre-HoLEP urethrocystoscopy, and prostate cancer and not just the enlarged prostate and so they did not qualify for 
the measurements that were taken. Of the 40 patients, three $(7.50 \%)$ patients were transfused pre- and intra-op on account of low hematocrits prior to surgery. Twenty seven out of the 40 patients were not transfused before, during or after surgery. Two (5.00\%) patients were recatheterized after surgery for failure to pass urine which resolved after 3 more days of catheterization. One (2.50\%) patient had urethrocystoscopy following HoLEP for post-operative haematuria. This patient had urethral injury that was not recognized at surgery. Four $(10.00 \%)$ other patients had urethrocystoscopy for obstructive voiding symptoms within the 6 months after surgery and transurethral incision of the bladder neck (TUIBN) was done. One $(2.50 \%)$ patient had bipolar TURP one month after HoLEP. His prostate gland was $252 \mathrm{~g}$, very fibrotic from chronic prostatitis. The repeat surgery was a planned procedure to take out any residual tissue not completely enucleated in the first session.

For the 12 patients who have returned for follow up, the average age of patients was 64.83 years (Table 3). A comparison of the pre- and post-operative changes are shown below.

Table 3 Post-operative characteristics

\begin{tabular}{lccc}
\hline Characteristics & $\begin{array}{l}\text { Pre- } \\
\text { operative } \\
\text { mean }\end{array}$ & $\begin{array}{l}\text { Post- } \\
\text { operative } \\
\text { mean }\end{array}$ & P value \\
\hline IPSS & 19.67 & 5.41 & 0.000 \\
PSA $(\mathrm{ng} / \mathrm{ml})$ & 8.07 & 2.03 & 0.001 \\
Prostate size $(\mathrm{g})$ & 116.54 & 30.3 & 0.000 \\
Residual urine volume $(\mathrm{ml})$ & 88.99 & 32.8 & 0.223 \\
$Q_{\text {max }}(\mathrm{ml} / \mathrm{s})$ & 11.27 & 29.67 & 0.000 \\
\hline
\end{tabular}

\section{Discussion}

BPH is a relatively common condition in Nigerian Urology clinics. However, while open surgery and TURP are relatively common surgical modalities of treatment, HoLEP is not common. To the best of our knowledge, only our centre offered this procedure in Nigeria in 2019. Compared to open prostatectomy and TURP, HoLEP offers significantly lower post-operative morbidity, shorter catheterization time and post-operative hospital stay [14]. It has been shown to provide relief from LUTS due to $\mathrm{BPH}$, and this was replicated in our experience (See Fig. 1).

While our findings are in keeping with those of others that $\mathrm{BPH}$ occurs in the elderly, in comparison to all other centres whose studies we reviewed [7, 18-21], our patients were relatively younger. It has been established that prostate cancer is more common [22] and occurs at a younger age [23] in blacks. The factors responsible for this may also be responsible for early-onset BPH seen in men of African descent, the race to which all our patients belonged.

The average pre-operative prostate size in our experience was higher than those seen elsewhere [7, 18, 24, 25]. While there has been no consensus statement about the impact of race on prostate sizes [26, 27], prostates of Asians have been found to be generally smaller than their western counterparts [28]. Irrespective of sizes seen, which were larger than those found in other parts of the world, all prostates were still enucleated and morcellated successfully with a sonographically estimated mean resected tissue volume of $86.24 \mathrm{ml}$. All patients except one had complete enucleation of their prostates in one session. In Turkey, a research team reported a

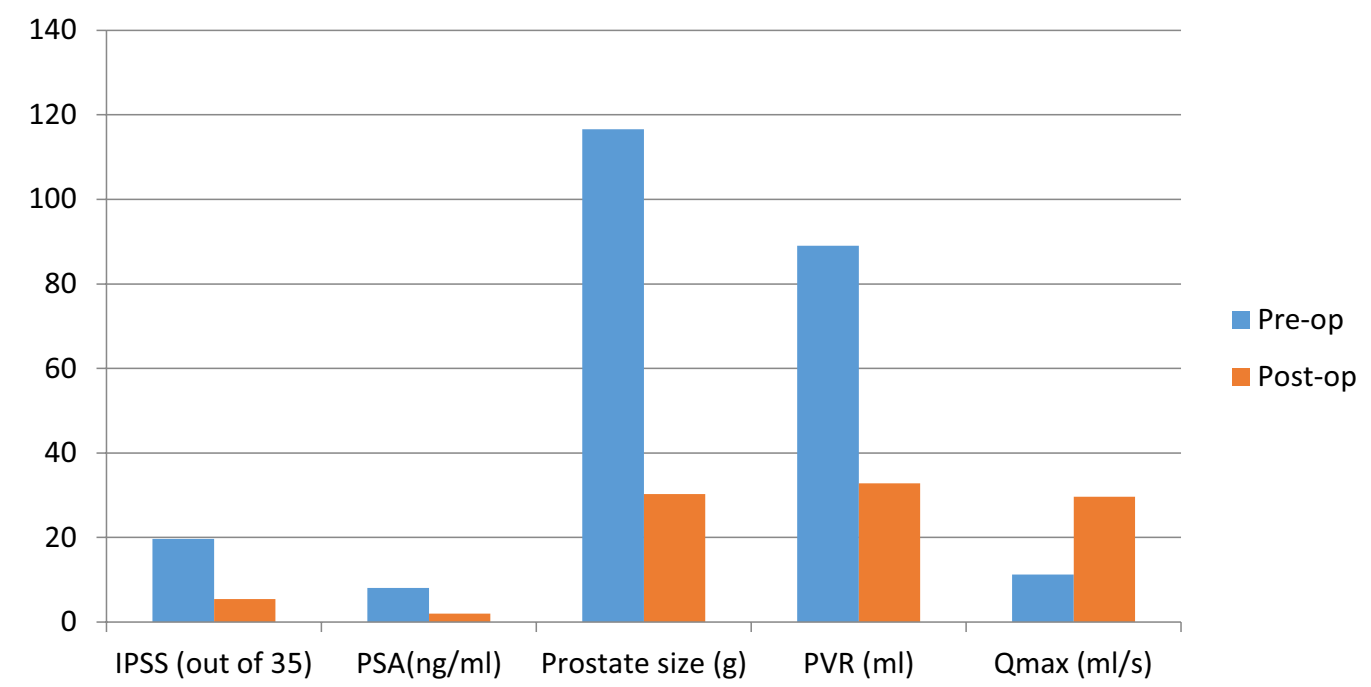

Fig. 1 Pre-and post-outcome scores of all understudied patients 
morcellated prostate volume of $29.2 \pm 11 \mathrm{ml}$ [11], while another team reported that the resected adenoma volume was $52.3 \pm 8.3 \mathrm{ml}$ [29]. In South Korea, a sonographically calculated resected prostate tissue volume of $29.2 \pm 20.1 \mathrm{ml}$ [30] was reported in keeping with our observation that prostates we see in Nigeria or Africa presenting for surgery are much bigger than those seen in several other continents.

The PSA values of the patients were higher than those reported by other authors from outside Africa [7, 31, 32]. PSA values usually correlate positively with prostate sizes [33-37] in patients who otherwise do not have prostate cancer. The PSA values in our experience are thus reflective of the huge prostate sizes in our environment. Some of the patients with high PSA values who did not have cancer also had prostatitis (acute, chronic, or acute-onchronic). The PSA rise and fall pre- and post-surgery thus hypothetically reflects the large prostate sizes in our environment and the post-operative reduction in prostate volume following enucleation of prostatic tissue during HoLEP.

Post-void residual urine volume does not always correlate with the degree of mechanical obstruction, because sometimes, it is due to other factors and not just the mechanical obstruction. But when it is used in conjunction with other parameters, its sensitivity is increased [38] and in patients with $\mathrm{BPH}$, it is an important indication for surgery. In our patients, the average pre-operative PVR was $203.98 \mathrm{ml}$. Reports from other centres have shown similarly high PVR volumes in BPH patients presenting for surgery $[11,20,39]$. The mean pre-operative post-void residual volume was found to be lower than that in another centre [11]. This is probably because some of the patients were catheterized prior to surgery and so their pre-op PVRs were not computed. Also, one patient had surgery because he did not want to continue with medical treatment and not because he was retaining urine at the time of surgery.

A low $Q_{\max }$ is highly suggestive of obstruction [39]. This was the case in this study. Though the pre-operative $Q_{\max }$ in our experience was higher than that found in other studies [7, 20,25, 40], the change in $Q_{\max }$ was still statistically significant with better post-operative results. One of these patients opted for surgery to reduce the number of medications he had to take for multiple medical conditions, even though he was doing well on medical treatment for $\mathrm{BPH}$, and this may have contributed to this finding.

Compared to reports of other authors we reviewed [11, $18,20]$, our patients had the shortest duration of postoperation catheterization. The length of hospital stay in our experience was comparable to those reported from other centres $[11,18,20,41,42]$. With significantly lower durations of irrigation and catheterization post-surgery, some patients could be discharged home without catheters within $24 \mathrm{~h}$ of surgery when they were able to void without complaints.

A significant improvement in symptoms is one of the aims of surgery for BPH. We observed a $72.5 \%$ change in pre- and post-operative IPSS in our initial experience. This is in agreement with several reports from other authors which reported significant improvements in symptom scores after surgery [11, 20, 25, 42].

Capsular perforation was reported in as much as $9.6 \%$ of patients who had HoLEP in one study [16]. In our experience though, no patient had capsular perforation or superficial bladder mucosa injury. It is said that following HoLEP, 0-12.1\% [16] of patients will require recatheterization. Two $(5.00 \%)$ of our patients were recatheterized for failure to pass urine which resolved after 3 more days of catheterization. This compares favourably to studies which recorded 6.4\% [43] and 3.9\% [16] incidents of recatheterization following HoLEP.

A total of 5 (12.5\%) patients had cystoscopy following surgery. One was for post-operative hematuria due to unrecognized urethral injury at surgery, while the other four patients had urethrocystoscopy for earlyonset obstructive voiding symptoms. Bladder neck contracture (BNC) reportedly occurs in $0.3-9.7 \%$ [44] of patients following surgery for BPH. In Indiana, USA, this was observed in 3.9\% [45] of patients after HoLEP while in Maharashtra, India and Montreal, Canada, $0.35 \%$ [16] and $0.8 \%$ [18] of patients respectively developed BNC following HoLEP. In our early experience, $4(10.0 \%)$ of our patients had TUIBN for BNC within 6 months after HoLEP, which is close to reported figures. At the moment, we have reduced intensity of coagulation to avert post-operative bladder neck stenosis. Urethral stricture was not found to be responsible for obstructive voiding symptoms in any patient who had these within the 6-month follow-up period.

Early incontinence is said to occur in up to $44 \%$ of patients after HoLEP while late iatrogenic stress incontinence has been reported in 0-2.4 [16] cases. Up to $32.7 \%$ of patients in one study [46] had urinary incontinence at 6 months. Another study reported long-term incontinence in $12.6 \%$ [47] of patients. In our experience, none of our patients who had returned for follow-up was incontinent at their review 6 months after surgery.

\section{Conclusion}

The outcome of HoLEP in our early experience was similar to and in some aspects, somewhat better than those from other parts of the world. The possibility of complications in the hands of the beginner and the prolonged learning curve should therefore not be a hindrance to 
commencement of HoLEP in Nigeria as excellent results can still be achieved even at a very early stage.

\section{Limitations}

The sample size is too small to make a more generalized statement. A larger study will need to be done with longterm follow up to get a clearer picture of the situation with HoLEP in our environment.

\begin{abstract}
Abbreviations
AUA: American Urological Association; BNC: Bladder neck contracture; BOO: Bladder outlet obstruction; BPH: Benign prostatic hyperplasia; EAU: European Association of Urology; HoLEP: Holmium laser enucleation of the prostate; IPSS: International Prostate Symptom Score; LUTS: Lower urinary tract symptoms; PSA: Prostate-specific antigen; PVR: Post-void residual urine volume; Qmax: Maximum flow rate; QoL: Quality of life; TUIBN: Transurethral incision of bladder neck; TURP: Transurethral resection of the prostate; UTI: Urinary tract infection.
\end{abstract}

\section{Acknowledgements}

We acknowledge the role of Prof. Friday Odey who provided editorial assistance prior to submission.

\section{Authors' contributions}

CUU conceptualized and designed the research. EIN collected and interpreted patients' data. KRT contributed to interpretation of the results, prepared the figure and tables and extensively reviewed all references. All authors discussed the results and were major contributors in writing the manuscript. All authors read and approved the final manuscript.

\section{Funding}

Kelina Hospital, Abuja was the source of funding for the research, from participant's recruitment, data collection and analysis to writing the manuscript.

\section{Availability of data and materials}

The datasets used and/or analysed during the current study are available from the corresponding author on reasonable request.

\section{Declarations}

\section{Ethics approval and consent to participate}

Ethical approval for the study was given by the Federal Capital Territory Health Research Ethics Committee with Approval Number: FHREC/2O2O| 01/112/03-11-20.

\section{Consent for publication}

Not applicable.

\section{Competing interests}

The authors declare that they have no competing interests.

Received: 21 December 2020 Accepted: 12 June 2021

Published online: 30 June 2021

\section{References}

1. Ezeanyika LUS, Ejike CECC, Elom SO (2006) Prostate disorders in an apparently normal Nigerian population 1: prevalence. Biokemistri 18(2):127132. https://doi.org/10.4314/biokem.v18i2.56413

2. Ejike CECC, Eze KC (2015) Prevalence of symptoms of benign prostatic hyperplasia in Umudike and its relationship with measures of obesity. Asian J Clin Nutr 7(1):1-8. https://doi.org/10.3923/ajcn.2015.1.8

3. Chokkalingam AP, Yeboah ED, Demarzo A, Netto G, Yu K, Biritwum RB et al (2012) Prevalence of BPH and lower urinary tract symptoms in West
Africans. Prostate Cancer Prostatic Dis 15(2):170-176. https://doi.org/10. 1038/pcan.2011.43

4. Foster HE, Barry MJ, Dahm P, Gandhi MC, Kaplan SA, Kohler TS et al (2018) Surgical management of lower urinary tract symptoms attributed to benign prostatic hyperplasia: AUA guideline. J Urol 200(3):612-619. https://doi.org/10.1016/j.juro.2018.05.048

5. Foster HE, Dahm P, Kohler TS, Lerner LB, Parsons JK, Wilt TJ et al (2019) Surgical management of lower urinary tract symptoms attributed to benign prostatic hyperplasia: AUA guideline amendment 2019. J Urol 202(3):592-598. https://doi.org/10.1097/JU.0000000000000319

6. Dhingra N, Bhagwat D (2011) Benign prostatic hyperplasia: an overview of existing treatment. Indian J Pharmacol 43(1):6-12. https://doi.org/10. 4103/0253-7613.75657

7. Lee YJ, Oh SA, Kim SH, Oh SJ (2017) Patient satisfaction after holmium laser enucleation of the prostate (HoLEP): a prospective cohort study. PLoS ONE 12(8):e0182230. https://doi.org/10.1371/journal.pone.0182230

8. Aho TF (2013) Holmium laser enucleation of the prostate: a paradigm shift in benign prostatic hyperplasia surgery. Ther Adv Urol 5(5):245-253. https://doi.org/10.1177/1756287213498923

9. Oelke M, Bachmann A, Descazeaud A, Emberton M, Gravas S, Michel MC et al (2013) EAU guidelines on the treatment and follow-up of non-neurogenic male lower urinary tract symptoms including benign prostatic obstruction. Eur Urol 64(1):118-140. https://doi.org/10.1016/j. eururo.2013.03.004

10. Gilling PJ, Cass CB, Cresswell MD, Fraundorfer MR (1996) Holmium laser resection of the prostate: preliminary results of a new method for the treatment of benign prostatic hyperplasia. Urology 47:48-51

11. Alkan I, Ozveri H, Akin Y, Ipekci T, Alican Y (2016) Holmium laser enucleation of the prostate: surgical, functional, and quality-of-life outcomes upon extended follow-up. Int Braz J Urol 42(2):293-301. https://doi.org/ 10.1590/S1677-5538.IBJU.2014.0561

12. Elzayat EA, Habib El, Elhilali MM (2015) Holmium laser enucleation of the prostate: a size-independent new "gold standard." Urology 66(5 Suppl):108-113. https://doi.org/10.1016/j.urology.2005.06.006

13. Gravas S, Cornu JN, Gacci M, Gratzke C, Herrmann TRW, Mamoulakis C et al (2019) EAU guidelines on management of non-neurogenic male lower urinary tract symptoms (LUTS), incl. Benign Prostatic Obstruction (BPO). https://uroweb.org/wp-content/uploads/EAU-Guidelines-on-theManagement-of-Non-Neurogenic-Male-LUTS-2019.pdf. Accessed 18 Feb 2020

14. Kim SH, Yoo C, Choo M, Paick JS, Oh SJ (2014) Factors affecting de novo urinary retention after Holmium laser enucleation of the prostate. PLoS ONE 21(1):e84938. https://doi.org/10.1371/journal.pone.0084938

15. Suardi N, Gallina A, Salonia A, Briganti A, Dehò F, Zanni G et al (2009) Holmium laser enucleation of the prostate and holmium laser ablation of the prostate: indications and outcome. Curr Opin Urol 19(1):38-43. https:// doi.org/10.1097/MOU.0b013e32831a7008

16. Shah HN, Mahajan AP, Hegde SS, Bansal MB (2007) Peri-operative complications of holmium laser enucleation of the prostate: experience in the first 280 patients, and a review of literature. BJU Int 100(1):94-101. https:// doi.org/10.1111/j.1464-410X.2007.06867.x

17. Shah HN, Mahajan AP, Sodha HS, Hegde S, Mohile PD, Bansal MB (2007) Prospective evaluation of the learning curve for holmium laser enucleation of the prostate. J Urol 177(4):1468-1474. https://doi.org/10.1016/j. juro.2006.11.091

18. Elzayat EA, Elhilali MM (2007) Holmium laser enucleation of the prostate (HoLEP): long-term results, reoperation rate, and possible impact of the learning curve. Eur Urol 52(5):1465-1471. https://doi.org/10.1016/j. eururo.2007.04.074

19. Vassori I, Valenti S, Naspro R, Vismara A, Dell'Acqua V, Manzetti A, Hurle R (2008) Three-year outcome following holmium laser enucleation of the prostate combined with mechanical morcellation in 330 consecutive patients. Eur Urol 53(3):599-604. https://doi.org/10.1016/j.eururo.2007.10. 059

20. Jhanwar A, Sinha RJ, Bansal A, Prakash G, Singh K, Singh V (2017) Outcomes of transurethral resection and holmium laser enucleation in more than $60 \mathrm{~g}$ of prostate: a prospective randomized study. Urol Ann 9(1):45-50. https://doi.org/10.4103/0974-7796.198904

21. Zhang MW, El Tayeb MM, Borofsky MS, Dauw CA, Wagner KR et al (2017) Comparison of perioperative outcomes between holmium laser 
enucleation of the prostate and robot-assisted simple prostatectomy. J Endourol 31(9):847-850. https://doi.org/10.1089/end.2017.0095

22. Lloyd T, Hounsome L, Mehay A, Mee S, Verne J, Cooper A (2015) Lifetime risk of being diagnosed with, or dying from, prostate cancer by major ethnic group in England 2008-2010. BMC Med 13:171. https://doi.org/10. 1186/s12916-015-0405-5

23. Evans S, Metcalfe C, Patel B, Ibrahim F, Anson $\mathrm{K}$, Chinegwundoh F et al (2010) Clinical presentation and initial management of black men and white men with prostate cancer in the United Kingdom: the PROCESS cohort study. Br J Cancer 102(2):249-254. https://doi.org/10.1038/sj.bjc. 6605461

24. Pirola GM, Saredi G, Codas Duarte R, Bernard L, Pacchetti A, Berti L et al (2018) Holmium laser versus thulium laser enucleation of the prostate: a matched-pair analysis from two centers. Ther Adv Urol 10(8):223-233. https://doi.org/10.1177/1756287218779784

25. Barboza L, Malafaia O, Slongo LE, Meyer F, Nassif PAN, Tabushi Fl et al (2015) Holmium Laser enucleation of the prostate (HoLEP) versus Transurethral Resection of the Prostate (TURP). Rev Col Bras Cir 42(3):165-170. https://doi.org/10.1590/0100-69912015003007

26. Mavropoulos JC, Partin AW, Amling CL, Terris MK, Kane CJ, Aronson WJ et al (2007) Do racial differences in prostate size explain higher serum prostate-specific antigen concentrations among black men? Urology 69(6):1138-1142. https://doi.org/10.1016/j.urology.2007.01.102

27. Platz EA, Kawachi I, Rimm EB, Willett WC, Giovannucci E (2000) Race, ethnicity and benign prostatic hyperplasia in the health professionals follow-up study. J Urol 163(2):490-495

28. Choi J, Ikeguchi EF, Lee SW, Choi HY, Te AE, Kaplan SA (2002) Is the higher prevalence of benign prostatic hyperplasia related to lower urinary tract symptoms in Korean men due to a high transition zone index? Eur Urol 42(1):7-11. https://doi.org/10.1016/s0302-2838(02)00222-1

29. Dogan S, Yildiz KY (2019) Our clinic's first experience with HoLEP. North Clin Istanb 6(4):355-360. https://doi.org/10.14744/nci.2019.24855

30. Oh JK, Ko KP, Oh SJ (2017) Measuring change in prostate size after holmium laser enucleation: a prospective study. Investig Clin Urol 58(3):200-204. https://doi.org/10.4111/icu.2017.58.3.200

31. Kimura OE, Aoki H, Ishidoya S (2019) Postoperative PSA levels after holmium laser enucleation of the prostate: enucleation ratio matters rather than preoperative prostate volume. Eur Urol Suppl 18(1):e1900-e1901. https://doi.org/10.1016/S1569-9056(19)31376-4

32. Elmansy HM, Elzayat EA, Sampalis JS, Elhilali MM (2009) Prostatic-specific antigen velocity after holmium laser enucleation of the prostate: possible predictor for the assessment of treatment effect durability for benign prostatic hyperplasia and detection of malignancy. Urology 74(5):11051110. https://doi.org/10.1016/j.urology.2009.06.039

33. Rupam D, Bijoyananda D, Mustafa AR (2017) A study of relationship of prostate volume, prostate specific antigen and age in benign prostatic hyperplasia. Int J Contemp Med Res 4(7):1582-1586

34. Bo M, Ventura M, Marinello R, Capello S, Casetta G, Fabris F (2003) Relationship between prostatic specific antigen (PSA) and volume of the prostate in the Benign Prostatic Hyperplasia in the elderly. Crit Rev Oncol Hematol 47(3):207-211. https://doi.org/10.1016/s1040-8428(03)00094-5

35. Alawad AM, Younis FH, Eltoum AM, Abdelgani SA (2014) Serum prostatespecific antigen as a predictor of prostate volume in Sudanese patients with benign prostatic hyperplasia. Int J Med 2(1):40-42. https://doi.org/ 10.14419/ijm.v2i1.2494

36. Coric J, Mujic J, Kucukalic E, Ler D (2015) Prostate-specific antigen (PSA) and prostate volume: better predictor of prostate cancer for Bosnian and Herzegovina men. Open Biochem J 9:34-36. https://doi.org/10.2174/ 1874091X01509010034

37. Hochberg DA, Armenakas NA, Fracchia JA (2000) Relationship of prostate-specific antigen and prostate volume in patients with biopsy proven benign prostatic hyperplasia. Prostate 45(4):315-319. https://doi. org/10.1002/1097-0045(20001201)45:4\%3c315::aid-pros5\%3e3.0.co;2-2

38. Asimakopoulos AD, De Nunzio C, Kocjancic E, Tubaro A, Rosier PF, Finazzi-Agrò E (2016) Measurement of post-void residual urine. Neurourol Urodynam 35(1):55-57. https://doi.org/10.1002/nau.22671

39. Ryoo HS, Suh YS, Kim TH, Sung HH, Jeong J, Lee KS (2015) Efficacy of holmium laser enucleation of the prostate based on patient preoperative characteristics. Int Neurourol J 19(4):278-285. https://doi.org/10.5213/inj. 2015.19.4.278

40. Meng F, Gao B, Fu Q, Chen J, Liu Y, Shi B et al (2007) Change of sexual function in patients before and after Ho:YAG laser enucleation of the prostate. J Androl 28(2):259-261

41. Baldini A, Fassi-Fehri H, Duarte R, Crouzet S, Ecochard R, Abid N et al (2016) Holmium laser enucleation of the prostate versus laparoscopic transcapsular prostatectomy: perioperative results and three-month follow-up. Curr Urol 10:81-86. https://doi.org/10.1159/000447156

42. Mir I, Date J, Shivde S, Patwardhan P, Deshmukh H (2017) Is HoLEP the only gold standard for surgical management of benign prostatic hyperplasia? Open J Urol 7(9):159-165. https://doi.org/10.4236/oju.2017.79019

43. Okamura K, Nojiri Y, Seki N, Arai Y, Matsuda T, Hattori R et al (2011) Perioperative management of transurethral surgery for benign prostatic hyperplasia: a nationwide survey in Japan. Int J Urol 18(4):304-310. https://doi. org/10.1111/j.1442-2042.2010.02712.x

44. Chen ML, Correa AF, Santucci RA (2016) Urethral strictures and stenosis caused by prostate therapy. Rev Urol 18(2):90-102. https://doi.org/10. 3909/riu0685

45. Kuo RL, Paterson RF, Siqueira TM Jr, Watkins SL, Simmons GR, Steele RE et al (2003) Holmium laser enucleation of the prostate: morbidity in a series of 206 patients. Urology 62(1):59-63. https://doi.org/10.1016/ s0090-4295(03)00124-9

46. Sapetti J, Sakat J, Saad E, Zerbib M, Belas O, Doru-Pop C et al (2019) Urinary incontinence after HOLEP: Incidence, evolution and predictive factors. Prog Urol 29(2):101-107. https://doi.org/10.1016/j.purol.2018.12. 008

47. Davydov DS, Tsarichenko DG, Bezrukov EA, Sukhanov RB, Vinarov AZ, Sorokin Nl et al (2018) Complications of the holmium laser enucleation of prostate for benign prostatic hyperplasia. Urologiia 1:42-47

\section{Publisher's Note}

Springer Nature remains neutral with regard to jurisdictional claims in published maps and institutional affiliations.

\section{Submit your manuscript to a SpringerOpen ${ }^{\circ}$ journal and benefit from:}

- Convenient online submission

- Rigorous peer review

- Open access: articles freely available online

- High visibility within the field

- Retaining the copyright to your article

Submit your next manuscript at $\gg$ springeropen.com 